Avaliable online at

https://www.syekhnurjati.ac.id/jurnal/index.php/tamaddun/index Published by Departement of History and Islamic Culture, Faculty of Ushuluddin Adab and Dakwah IAIN Syekh Nurjati Cirebon, Indonesia

\title{
Menaklukkan Malam: Perkembangan Konsumsi Kopi di Negara Usmani pada Periode Modern Awal
}

Frial Ramadhan Supratman

Perpustakaan Nasional Republik Indonesia frialramadhan1@gmail.com

\begin{abstract}
Coffee is a drink that is very popular today. However, very few researchers focus research on coffee, especially in Muslim countries, such as the Ottoman countries. After coffee first arrived in Istanbul in the 16th century, the controversy over the coffee product itself began. The 16th and 17th centuries show that the Ottoman sultans did not always accept coffee as a halal product. This paper shows the dynamics of coffee consumption in the Ottoman State in the early modern period. The author wants to know how the consumption and perception of coffee in the Ottoman States. For this reason, the author describes the history of the emergence of coffee in Istanbul, the coffee shop's relationship with the Ottoman rulers to the coffee shop business controlled by the Janisary army. In this paper, the authors argue that coffee has had a dynamic development over time. Coffee has grown in popularity over time because the existence of coffee shops provided an effective means of communication for the Ottoman people in the early modern period.
\end{abstract}

Keywords : Coffee, Coffee Shop, Usmani State, Consumption, Early Modern

\begin{abstract}
ABSTRAK
Kopi merupakan minuman yang sangat disukai pada hari ini. Namun, sedikit sekali para peneliti yang memfokuskan penelitian mengenai kopi, khususnya di negara-negara Muslim, seperti Negara Usmani. Setelah kopi pertama kali datang di Istanbul pada abad ke-16, kontroversi mengenai produk kopi itu sendiri dimulai. Abad ke-16 dan 17 menunjukan bahwa para sultan Usmani tidak selalu dapat menerima kopi sebagai produk yang halal. Makalah ini menunjukan dinamika konsumsi kopi di Negara Usmani pada periode modern awal. Penulis ingin mengetahui bagaimana konsumsi dan
\end{abstract}


persepsi terhadap kopi di Negara Usmani. Untuk itu penulis menguraikan sejarah kemunculan kopi di Istanbul, relasi kedai kopi dengan penguasa Usmani hingga bisnis kedai kopi yang dikuasai oleh tentara Janisari. Dalam makalah ini penulis berargumen bahwa kopi mengalami perkembangan yang dinamis dari waktu ke waktu. Semakin lama kopi semakin disukai karena keberadaan kedai kopi telah menyediakan sarana komunikasi yang efektif bagi masyarakat Usmani pada periode modern awal.

Kata Kunci: Kopi, Kedai Kopi, Negara Usmani, Konsumsi, Modern Awal

\section{Pendahuluan}

Semerbak harum minuman berwarna hitam pekat telah tersebar kemana-mana. Sebuah kedai di distrik Tahtakale, Istanbul, menjadi sumbernya. Saat itu tidak ada yang mengenali minuman tersebut. Disinyalir minuman tersebut adalah sumber "kemalasan", karena di kedai tersebut orang-orang Usmani duduk santai, bermain catur, membaca syair, mengobrol, membunuh waktu hingga mereka lupa untuk pergi shalat. Melihat hal tersebut, mufti dan kadi Istanbul turun tangan. Investigasi dilakukan dan hasilnya adalah menyatakan bahwa minuman tersebut dan kedainya adalah haram. Minuman yang dimaksud adalah kopi. Dengan demikian kedai kopi pertama di Istanbul yang dibuka oleh seorang bernama Hakem dari Aleppo dan Sems dari Syam (Suriah) pada tahun 1554 juga dinyatakan haram. ${ }^{1}$

Siapa yang menyangka bahwa pribahasa "cinta pada pandangan pertama" ternyata tidak berlaku untuk kopi (dalam bahasa Turki disebut kahve, sedangkan dalam bahasa Arab disebut qahwa). Meskipun hari ini kopi begitu digemari, namun kopi pernah

${ }^{1}$ Robert Mantran, XVI-XVIII Yüzyılda Osmanlı Imparatorluğu (penerjemah: Mehmet Ali Kılıçbay) (Ankara: İmge Kitabevi, 1995), hlm 60. 
mengalami sejarah pahit tersendiri, terutama ketika harumnya kopi mulai tersebar ke wilayah lain di luar Yaman. Seperti keterangan sebelumnya, di Istanbul kopi sempat dilarang karena telah menyebabkan kemalasan sehingga membuat produk ini memiliki citra negatif. Kemungkinan diharamkannya kopi pada saat itu dikarenakan keterbatasan informasi dan pengetahuan yang dimiliki oleh otoritas Usmani mengenai kopi. Ketika itu kopi baru saja diperkenalkan di Istanbul, Kairo dan berbagai wilayah lain. Dugaan negatif terhadap minuman ini cukup tinggi. Namun, seiring berjalannya waktu, kopi menjadi produk primadona. Hari ini, kita menyaksikan kopi Turki yang hitam dan pekat tersebut menjadi salah satu produk andalan Turki.

Kopi memang produk yang selalu jadi bahan perbincangan. Dari London, Amsterdam, Paris, Istanbul, Baghdad, Tehran, Jakarta hingga Rio de Janeiro, berbagai macam kedai kopi tersebar di manamana. Hampir tidak ada seorang pun di dunia ini yang tidak mengenal kopi. Minuman berwarna hitam pekat ini banyak dicari oleh dunia karena fungsinya untuk menjaga kantuk -menaklukan malam- dan menambah stamina tubuh. Di Indonesia sendiri, istilah "Ngopi dulu" seringkali digunakan anak-anak muda masa kini untuk menunjukan bahwa kopi dapat menambah konsentrasi, fokus dan kenikmatan dalam beraktifitas. Namun, nampaknya kajian sejarah mengenai kopi belum banyak dilakukan oleh para sejarawan. Dalam makalah ini, penulis akan mencoba melakukan penelitan dan kajian mengenai sejarah kopi di Negara Usmani. Seperti yang telah diketahui, sejak berdiri awal abad ke-14, Usmani memiliki wilayah 
yang sangat luas, membentang dari Afrika Utara, Balkan, Anatolia hingga Yaman. Dengan demikian luasnya, maka penulis akan melihat bagaimana pengaruh kopi terhadap konsumsi masyarakat. Penulis tidak membatasi tulisan ini dalam ruang lingkup sempit karena ingin mengetahui gambaran secara umum mengenai konsumsi di seluruh wilayah Usmani, meskipun, nampaknya, wilayah Istanbul, Anatolia dan Arab akan lebih mendominasi tulisan ini. Kemudian, penulis hanya membatasi penulisan ini pada periode modern awal (15001700) karena masa ini seringkali dianggap sebagai masa keemasan Negara Usmani. Jadi, penulis ingin mengetahui bagaimana konsumsi kopi masyarakat Usmani ketika kota-kota Usmani sedang berada dalam tingkat kesejahteraan yang cukup tinggi.

Tentunya penulis banyak berhutang kepada penelitianpenelitian sebelumnya yang banyak membahas mengenai kopi. Tulisan pertama mengenai sejarah kopi yang penulis baca adalah makalah dari Cemal Kafadar (2014). ${ }^{2}$ Dalam makalahnya, Kafadar menyatakan bahwa kemunculan kedai-kedai kopi di Istanbul, Kairo, Aleppo dan kota-kota lainnya bertepatan dengan perkembangan tiga aspek berikut: perkembangan level baru dalam urbanisasi yang diikuti oleh kebangkitan kelas borjuis; meningkatnya pemanfaatan waktu malam untuk melakukan sosialisasi, hiburan dan kerja; serta kemunculan bentuk baru dalam dunia hiburan, seperti teaterikal

${ }^{2}$ Cemal Kafadar, "How Dark is the History of Night, How the Black The Story of Coffee, How Bitter the Tale of Love: The Changing Measure of Leisure and Pleisure in Early Modern Istanbul," dalam Arzu Ozturkmen \& Evelyn Birge Vitz, Medieval and Early Modern Performances in the Eastern Mediterranean (Turnhout: Brepols, 2014), hlm 243-269. 
wayang Karagoz dan performa storytelling Meddah. ${ }^{3}$ Tulisan selanjutnya adalah dari buku karya Robert Mantran (1995). ${ }^{4}$ Dalam bukunya, Mantran juga sangat baik meneliti sejarah kopi di Istanbul pada abad ke-17. Istanbul tentu saja masih menjadi fokus utama tulisan ini karena berlimpahnya sumber primer mengenai Istanbul. Selanjutnya, terdapat buku dari Sarah Birsel (1983) yang menceritakan mengenai riwayat kopi. ${ }^{5}$ Karya ini sangat baik untuk memahami sejarah kopi karena ditulis dengan gaya yang populer. Tulisan selanjutnya adalah buku bunga rampai yang dieditori oleh Ahmet Yasar (2010). ${ }^{6}$ Kumpulan tulisan dalam buku ini sangat membantu penulis untuk memahami kopi dengan baik. Selanjutnya, tentu saja, ada artikel yang ditulis oleh Ali Caksu (2017) dan Alan Mikhail (2017). ${ }^{7}$ Dalam artikelnya, Çaksu menguraikan bagaimana bisnis kedai kopi dilakukan pada abad ke-18, terutama dengan adanya keterlibatan tentara Janisari dalam bisnis tersebut. Dengan berbagai macam penelitian mengenai kopi, maka penulis sangat terbantu untuk dapat memberikan informasi mengenai sejarah kopi dengan baik.

\section{Kemunculan Kopi di Negara Usmani}

${ }^{3}$ Kafadar, "How Dark is the History of Night, How the Black The Story of Coffee, How Bitter the Tale of Love," hlm 244.

${ }^{4}$ Robert Mantran, XVI-XVIII Yüzyılda Osmanlı Imparatorluğu, hlm 60.

${ }^{5}$ Salah Birsel, Kahveler Kitabı (Ankara: Türkiye İş Bankası Kültür Yayınları, 1983)

6 Ahmet Yaşar (ed), Osmanlı Kahvehaneleri: Mekan, Sosyalleşme, Iktidar (Istanbul: Kitap Yayinevi, 2010).

7 Alan Mikhail, "The Heart's Desire: Gender, Urban, Space, and Ottoman Coffee House," dalam Dana Sajdi (ed), Ottoman Tulips, Ottoman Coffee: Leisure and Lifestyle in the Eighteenth Century (New York \& London: IB Tauris, 2007); Ali Çaksu, "Janissary Coffee House in Late Eighteenth Century Istanbul" Dana Sajdi (ed), Ottoman Tulips, Ottoman Coffee: Leisure and Lifestyle in the Eighteenth Century (New York \& London: IB Tauris, 2007). 
Pada 1517, Selim I (1512-1520) dan pasukannya menyebrangi gurun Sinai. Mereka menantang Negara Mamluk yang berpusat di Mesir. Dengan kekuatan besar yang dibawanya, akhirnya Mamluk dapat ditaklukan oleh Selim I. Dengan tenang, Selim I kemudian memasuki Kairo dan disambut oleh para warga di sana. Dengan ditaklukannya Kairo, maka Selim I menerima legitimasi sebagai penjaga Haramayn atau (Khadimul Haramayn). ${ }^{8}$ Selain itu, wilayahwilayah Arab lainnya juga tunduk kepada Selim I. Dikuasainya Arab, telah memudahkan Negara Usmani untuk menyatukan sistem perdagangan antara Istanbul dan kota-kota Arab, seperti Damaskus, Aleppo dan Kairo. Kemudian, Baghdad juga akan disatukan dalam jalur perdagangan Usmani. Berbagai macam barang dagang, mulai dari kuda, porselein, sutera, rempah-rempah hingga kopi dapat ditemukan di berbagai macam kota-kota dagang di Arab. Kemungkinan besar, kopi masuk wilayah Usmani melalui kegiatan ekonomi pasca penaklukan Kairo 1517. Sekarang, kita harus mencari tahu terlebih dahulu dari manakah kopi berasal dan bagaimana persebarannya.

Sebelum terjadi kontak dengan Arab, nampaknya orang-orang Rum (mengacu pada masyarakat yang tinggal di Anatolia dan Balkan) tidak memiliki pengetahuan mengenai kopi. Terdapat karya dari seorang ahli Pharmacognosy Armenia yang bekerja di Istana Topkapi, Istanbul, pada masa Sultan Mehmet II yang bernama Amirdovlat Amasiatsi (1420-1496) Dia mencatat nama-nama tumbuhan, tanaman dan hewan di tempat-tempat yang dia ketahui.

\footnotetext{
${ }^{8}$ Selahattin Tansel, Yavuz Sultan Selim (Ankara: Milli Eğitim Basımevi: 1969), hlm 211. 279
} 
Namun, dalam karyanya yang ditulis pada 1478, Amirdovlat tidak memiliki catatan mengenai kopi. Menurut sejarawan Cemal Kafadar (2014), dokumen awal yang mencatat kata kopi atau kahve adalah dokumen yang berisi sumbangan properti dari Barbaros Hayreddin Pasa (1473-1546). Dalam dokumen tersebut, Barbaros Hayreddin memberikan sumbangan berupa sebuah rumah sebagai wakaf keluarga. Pada dokumen yang ditulis pada tahun 1539 tersebut terdapat beberapa properti Barbaros Hayreddin yang bernama kahve odası (ruangan kopi). ${ }^{9}$ Hal tersebut tidaklah mengherankan karena Barbaros Hayreddin Paşa adalah seorang laksamana Usmani yang familiar dengan Laut Mediterania. Kemungkinan besar dia berinteraksi dengan pedagang Arab yang membawa produk kopi.

Salah satu intelektual Usmani yang menulis mengenai kopi adalah Katip Çelebi yang hidup pada abad ke-17. Katip Celebi atau Haji Mustafa merupakan seorang intelektual Usmani yang banyak menulis buku mengenai ilmu bumi, sejarah dan agama. Menurut Katip Çelebi, kopi ditemukan di daerah pegunungan yang ada di Yaman. ${ }^{10}$ Para darwis atau sufi adalah kelompok yang menemukan tanaman kopi ini. Tidak jelas kapan kopi mulai ditemukan oleh para sufi ini, namun ketika tanaman kopi ini ditemukan lalu dimakan maka menimbulkan "kebahagiaan." Menurut utusan Swiss untuk Negara Usmani, Ignatius Mouradja D'Ohsson, dan sejarawan Ahmet Efendi, kopi pertama kali ditemukan oleh seorang syaikh dari tarekat

${ }^{9}$ Kafadar, "How Dark is the History of Night, How the Black The Story of Coffee, How Bitter the Tale of Love," hlm 247.

10 Katip Çelebi, Mizanu'l- hak fi ihtiyari'l - ehak: İslam'da Tenkid ve Tartışma Usulu (editor: Suleyman Uludag \& Mustafa Kara) (İstanbul: Marifet Yayınları, 1990), hlm 74. 
Syadziliah di wilayah Mokha, Arab. ${ }^{11}$ Menurut Katip, orang-orang Yaman menggunakan kopi untuk menyegarkan tubuhnya. Biji kopi tersebut direbus, kemudian diminum. ${ }^{12}$ Sebenarnya Katip Celebi bukanlah orang pertama yang menulis mengenai kopi. Banyak penulis-penulis Usmani yang juga memiliki perhatian terhadap produk unggulan asal Arab ini. Pada abad ke-16 dan 17, para penulis Usmani telah banyak yang membahas produk kopi, diantaranya Selaniki Mustafa Efendi, Mustafa Naima, Mustafa Ali, Katip Çelebi, İbrahim Peçevi, Hezarfen Hüseyin Efendi, Hafız Hüseyin Ayvansarayı, Evliya Çelebi dan Defterdar Sarı Mehmet Paşa. ${ }^{13}$ Perhatian para intelektual Usmani terhadap kopi tidak dapat dilepaskan dari kontroversi mengenai kemunculan kopi itu sendiri.

Sebelum kopi sampai di Istanbul, produk ini terlebih dahulu dijual di Mekah pada akhir abad ke-15. Produk ini dibawa oleh seorang pedagang bernama Hayri Bey. Setelah kopi diinvestigasi, maka kopi dinyatakan sebagai produk haram pada 1511 sehingga jual beli kopi dilarang. Kedai kopi pun kemudian terlarang untuk dibuka. Namun, pada 1512, Hayri Bey kembali membuka jual beli kopi. Di Mesir, produk kopi pun dinyatakan haram oleh para ahli fikih atau fuqaha. ${ }^{14}$ Setelah Sultan Selim I menaklukan negara-negara Arab, termasuk Mesir, maka kopi mulai masuk ke dalam Negara Usmani, khususnya Istanbul. Terdapat beberapa pendapat mengenai

${ }^{11}$ Salah Birsel, Kahveler Kitabı, hlm 11.

${ }^{12}$ Salah Birsel, Kahveler Kitabı, hlm 10.

13 Ahmet Yaşar "Giriş: Geçmişini Arayan Osmanlı Kahvehanesi", dalam Ahmet Yaşar (ed), Osmanlı Kahvehaneleri: Mekan, Sosyalleşme, iktidar (Istanbul: Kitap Yayinevi, 2010), hlm 11-12.

${ }^{14}$ Robert Mantran, XVI-XVIII Yüzyılda Osmanlı Imparatorluğu, hlm 59. 
masuknya kopi. Penulis Usmani, Peçevi İbrahim Efendi (1574-1649) menyatakan jika kedai kopi pertama dibuka pada 1554-1555. Terdapat beberapa teori mengenai masuknya kopi ke Istanbul, salah satunya yang menyatakan bahwa kopi dibawa oleh para jamaah haji yang kembali dari Mekah. Kemungkinan besar juga, sebelum sampai ke Istanbul, kopi sudah tersebar di berbagai wilayah Anatolia dan Rumeli (Balkan). ${ }^{15}$ Persebaran kopi di Negara Usmani dapat dilihat dari catatan pajak pada masa pemerintahan Sultan Suleyman Kanuni (1520-1566). Menurut dokumen pajak, pemerintah Usmani sudah menetapkan bea masuk untuk produk kopi yakni sebesar 8 akçe untuk pedagang Muslim dan 10 akçe untuk non-Muslim. ${ }^{16}$

\section{Dibukanya Kedai Kopi}

Pada abad ke-16, kopi sudah masuk ke Istanbul. Tentu saja hal ini tidak diragukan karena Istanbul merupakan kota yang kosmopolit dan terbuka untuk melakukan perdagangan. Para pedagang dari berbagai wilayah dunia datang ke kota ini untuk melakukan perdagangan. Para pedagang Eropa yang membina hubungan baik dengan Usmani diberi Ahdname untuk menjamin keamanan selama melakukan perdagangan di negara Usmani. Selain itu, sistem wakaf telah mendorong adanya pembukaan fasilitas perdagangan, seperti pasar dan kervansaray. Sultan Mehmet II Fatih (1444-1481) bahkan membuka sebuah pasar tertutup yang sangat besar yang bernama Pasar Kapalıçarsi atau Grand Bazar. Fasilitas inilah yang telah menarik para pedagang untuk mengembangkan bisnisnya di Istanbul.

15 Suraiya Faroqhi, Osmanlı Kültürü ve Gündelik Yaşam: Ortaçağdan Yirminci Yüzyıla (penerjemah: Elif Kılıç)(i̇stanbul: Tarih Vakfı, 2005), hlm 59.

${ }^{16}$ Robert Mantran, XVI-XVIII Yüzyılda Osmanlı Imparatorluğu, hlm 60. 
Salah satu catatan mengenai dibukanya kedai kopi pertama di Negara Usmani terdapat dalam manuskrip Tarih-i Peçevi karya İbrahim Peçevi Efendi. Menurut Peçevi, sebelum tahun 962 (1554), tidak ada kopi dan kedai kopi di wilayah Rum. Namun, kopi kemudian masuk ke wilayah Usmani dengan dibawa oleh seorang pedagang bernama Hakem asal Aleppo dan Sems dari Syam. Diketahui bahwa Sems membuka kedai kopi untuk pertama kalinya di distrik Tahtakale, Istanbul. Di kedai kopi tersebut, orang-orang berkumpul untuk membaca buku, bermain catur, hingga membacakan syair-syair. Di sana mereka menghabiskan uangnya sekitar satu atau dua akce untuk membeli kopi. ${ }^{17}$ Di kedai kopi juga masyarakat Usmani mendapatkan kesenangan dan hiburan karena disanalah mereka dapat mendengarkan pembacaan syair-syair. Aşık Garıb menulis bagaimana dia menemui seorang penyair yang menjadi terkenal dan mendapat bayaran tinggi karena dia selalu mendatangi kedai-kedai kopi. Di sana penyair tersebut berkompetisi dan membacakan syair-syairnya hingga dia menjadi terkenal. ${ }^{18}$ Kehadiran kedai kopi ternyata meresahkan para elite agama Usmani. Pecevi menyatakan bahwa "tidak ada satupun yang mendatangi masjid". Kedai kopi disamakan dengan meyhanne atau kedai arak yang disimbolkan dengan keburukan. Adanya ketakutan akan keburukan yang ditimbulkan oleh kedai kopi, maka dikeluarkankanlah fatwa haram terhadap kedai kopi. Cerita mengenai fatwa haram terhadap

17 Peçevi İbrahim Efendi, Peçevi Tarihi I (editor: Bekir Sıtkı Baykal) (Ankara: Kültür Bakanlığı Yayınları, 1981), hlm 258.

${ }^{18}$ Kafadar, "How Dark is the History of Night, How the Black The Story of Coffee, How Bitter the Tale of Love," hlm 17. 
kopi juga ditulis oleh Katip Çelebi dalam kitab Mizan'ul-hakk fi ihtiyar'l-ahakk. Dalam ceritanya, Katip menyatakan bahwa kopi diharamkan karena pernah terjadi kebakaran ketika sedang merebus biji kopi. ${ }^{19}$ Pada zaman Murat III (1574-1595) juga maka kopi diharamkan di Negara Usmani. ${ }^{20}$ Ebusuud Efendi merupakan seorang seyhulislam Usmani yang mendukung fatwa haram terhadap kopi. Bahkan Ebusuud menginstruksikan agar kapal-kapal yang membawa kopi ditenggelamkan. ${ }^{21}$

Kemunculan kopi untuk pertama kalinya di Negara Usmani telah memantik perdabatan yang sengit diantara ulama Usmani itu sendiri. Perdebatan itu seringkali direkam dalam syair-syair yang ditulis oleh para ulama kepada ulama lain, bahkan syaikhulislam. Salah satu syair pernah ditulis oleh İştipli Vaiz Emir Efendi untuk Syaikhulislam Bostanzade Mehmet Efendi (menjadi syaikhulislam pada 1589-1592; 1593-1598). İştipli Vaiz Emir Efendi menulis syair 12 bait untuk menunjukan bahwa kopi tidak berbahaya, tidak melawan agama, bahkan dapat memberikan kesehatan untuk yang meminumnya. Bostanzade kemudian menjawab bahwa kopi adalah minuman yang berbahaya. ${ }^{22}$ Melalui syairnya juga Nevi (wafat 1598) mempertanyakan mengapa orang-orang yang menjual kopi dianggap sebagai musuh dan apakah orang yang meminum kopi pantas dianggap sebagai kafir (keluar dari agama Islam). Nevi, bahkan,

${ }^{19}$ Ahmet Yaşar, "Erken Modern Osmanlı'da Kahvehane Yasakmaları," dalam Ahmet Yaşar (ed), Osmanlı Kahvehaneleri: Mekan, Sosyalleşme, iktidar (Istanbul: Kitap Yayinevi, 2010), hlm 37.

20 Peçevi İbrahim Efendi, Peçevi Tarihi I, hlm 258.

${ }^{21}$ Katip Çelebi, Mizanu'l- hak fi ihtiyari'l - ehak hlm 74. Untuk lebih detail mengenai biografi Ebusuud Efendi, lihat: Abdullah Aydemir, Ebusuud Efendi (Ankara: Kültür Bakanlığı Yayınları, 1989).

22 Namık Açıkgöz, Kahvename: Klasik Türk Edebiyatında Kahve (Ankara: Akçağ, 1999), hlm 10-11. 
menyatakan : "tanpa meminum dua gelas kopi, maka seorang guru tidak akan dapat membaca kitab pada malam hari, dan tidak dapat memberikan kuliah di pagi harinya." 23 Dengan demikian kemunculan kopi telah memunculkan perdebatan, baik dalam bidang hukum maupun syair-syair sosial. Kemunculan para penyair, seperti Nevi, dalam merespon kemunculan kopi telah menunjukan bahwa kopi telah menjadi bagian dari kehidupan sehari-hari masyarakat Usmani.

Meskipun pada awal kemunculannya kopi dianggap sebagai barang yang haram, namun perkembangan kedai kopi di Istanbul dan Anatolia berkembang dengan cukup cepat. Seorang pelancong Usmani, Evliya Çelebi, mencatat bahwa pada 1630 terdapat 55 kedai kopi. Bahkan Evliya menyatakan bahwa kebanyakan kedai-kedai kopi ini dimiliki oleh para guru sufi dari tarekat Syadziliah. Para syaikh sufi tersebut menyatakan bahwa mereka telah mendapatkan "izin" langsung dari Veysel Karani, seorang guru sufi yang ada di Yaman. ${ }^{24}$ Evliya Çelebi juga menyatakan bahwa para pegawai di kedai-kedai kopi ini mencapai 500 orang. ${ }^{25}$ Menurut Evliya Çelebi, pada masa pemerintahan Sultan Murat, kedai kopi dan kedai arak dilarang. ${ }^{26}$ Dengan demikian gambaran mengenai kedai kopi selalu buruk. Gambaran tersebut berlanjut hingga abad ke-17. Terdapat para sultan yang secara jelas melarang adanya kedai kopi. Pada masa pemerintahan Sultan Ahmet I (1603-1617), kedai kopi dilarang dan ditutup melalui pernyataan dari Dervis Paşa dan Nasuh Paşa. Begitu

\footnotetext{
${ }^{23}$ Namık Açıkgöz, Kahvename, hlm 13.

${ }^{24}$ Necdet Tosun, "Veysel Karani," dalam Diyanet Islam Ansiklopedisi jilid 43 (2013), hlm 74-75.

${ }^{25}$ Salah Birsel, Kahveler Kitabı, hlm 12.

${ }^{26}$ Evliya Çelebi, Günümüz Türkçesiyle Evliya Çelebi Seyahatnamesi: Istanbul (1.Kitap 1.Cilt) (editor: Seyit Ali Karaman Yüceli Dağlı) (İstanbul: Yapı Kredi Yayınları, 2006), hlm 287.
} 
pun pada masa Murat III (1546-1595), Osman II (1618-1622) dan Murat IV (1623/29-1640) kedai-kopi dilarang berdiri di Negara Usmani.

Pada masa pemerintahan Murat IV, terdapat kejadian besar di Istanbul yang membuat kedai kopi dilarang. Kejadian tersebut adalah adanya kebakaran besar yang melanda Istanbul. Pada 1633 terdapat kebakaran yang melanda Istanbul dan bermula dari api yang terdapat di Cibali Kapısı. Api kemudian menjalar hingga Ayakapısı dan Mustafa Paşa Çarşısı, Hamza Paşa Sarayı dan Yahya Paşa Sarayı. Bahkan api terus menyebar hingga Unkapanı dan Masjid Uskuplu. Menurut sejarawan Naima, kebakaran ini menyebabkan Sultan Murad IV mengeluarkan larangan untuk kedai kopi. Bahkan mereka yang tidak mematuhi aturan ini akan dieksekusi. Aturan ini berlaku bukan hanya untuk kota Istanbul saja, tetapi juga di berbagai wilayah Usmani lainnya. Di Edirne, misalnya, orang-orang yang tidak menutup kedai kopi bahkan harus menghadapi hukum gantung. ${ }^{27}$ Data-data tersebut menunjukan sejarah kelam dari kopi sebelum produk ini menjadi primadona hari ini.

Alasan lain mengapa kedai kopi menjadi "musuh" bagi pemerintah Usmani saat itu adalah karena kedai ini seringkali menjadi tempat persembunyian pada pemberontak. Para pemberontak pada Sultan Osman II, misalnya, seringkali bersembunyi di kedai kopi. ${ }^{28}$ Kedai kopi, tentu saja, menjadi tempat yang paling efektif dalam menyebarkan gosip, desas-desus, fitnah dan berita-berita seputar kejadian di dalam pemerintahan. Hal tersebut dikarenakan kedai kopi telah menjadi ruang publik (public

\footnotetext{
27 Salah Birsel, Kahveler Kitabı, hlm 14-15.

${ }^{28}$ Salah Birsel, Kahveler Kitabı, hlm 14.
} 
space) bagi masyarakat untuk melakukan komunikasi. Pada masa dimana tidak terdapat alat komunikasi masa yang efektif, maka kedai kopi menjadi semacam wadah untuk masyarakat dalam menyebarkan berita, mengomentari berita dan berdiskusi layaknya media sosial hari ini. Untuk itu tidaklah heran jika kedai kopi menjadi tempat berkumpulnya para pemberontak dan menjadi saran efektif untuk menyebarkan desas-desus.

Apapun efek dibukanya kedai kopi di wilayah-wilayah Usmani, namun, sebenarnya, kedai kopi muncul bersamaan dengan tumbuhnya komunitas urban. Seberapa keras fatwa haram yang ditujukan kepada kopi, namun minuman ini tetap menyebar di kalangan masyarakat. Intelektual dan ulama Usmani, Katip Çelebi menyatakan "Namun, larangan dan respon keras yang ditujukan terhadap kopi sama sekali tidak memberikan manfaat. Kata-kata dan fatwa yang diberikan sama sekali tidak masuk ke dalam telinga masyarakat."29 Perkataan Katip Çelebi benar karena meskipun kopi dilarang oleh sultan, namun kedai kopi tetap muncul di berbagai tempat, khususnya kota-kota besar seperti Istanbul dan Kairo. Dengan demikian dapat dikatakan bahwa kedai kopi merupakan fenomena urban yang terjadi bersamaan dengan kemunculan kota beserta dengan kehidupan sosial ekonominya. Meningkatnya perekonomian dari suatu kota menjadi daya tarik bagi bisnis kopi. Dengan meningkatnya perekonomian, maka kebutuhan sosial masyarakat untuk memiliki tempat sosialisasi dan berkumpul juga meningkat. Dalam konteks ini, kedai kopi menawarkan fungsi sosial

\section{7}

${ }^{29}$ Katip Çelebi, Mizanu'l- hak fi ihtiyari'l - ehak, hlm 74.

Tamaddun: Jurnal Sejarah dan Kebudayaan Islam, Volume (8), Issue (2),Desember 2020 
kepada masyarakat sebagai tempat berkomunikasi. Menurut sejarawan Naima, kedai kopi, bahkan, menjadi tempat para birokrat melakukan debat dan diskusi mengenai masalah-masalah negara. Sedangkan utusan Swiss untuk Usmani, D'Ohsson menyatakan bahwa kedai kopi adalah tempat untuk mendapatkan berita-berita yang terbaru. ${ }^{30}$

Di Istanbul, kopi dilarang dijual kecuali di Mısır Çarşısı (Pasar Mesir). Mısır Çarşısı adalah sebuah pasar yang terletak di distrik Eminonu, Istanbul. Letaknya tidak jauh dari Masjid Süleymaniye dan Rüstem Paşa. Di pasar inilah kopi dijual kepada para pedagang kopi. Dengan demikian, di Mısır Çarşısı banyak ditemukan kedai-kedai kopi. Selain di Mısır Çarşısı, banyak kedai kopi yang dibuka di Balık Pazariı(Pasar Ikan), Çavuşhane, Beyazid dan Galata. Selain itu juga terdapat kedai-kedai kopi yang dibuka di pinggiran jalan Tophane dan Ayasofya. Selain itu ada juga kedai-kedai kopi yang dibuka di distrik Kadırga dan Haliç. Karena kedai kopi juga menawarkan kesenangan dan hiburan, maka banyak kedai yang dibuka di pinggir Selat Bosphorus, seperti di wilayah Beyköz, İncirköy, Kanlıca, Hamam İskelesi, Çengelköy, Beylerbeyi dan Üsküdar. ${ }^{31}$

Selain Istanbul, Kairo merupakan kota dagang yang berkembang dengan sangat pesat. Jauhnya Kairo dari ibu kota Istanbul menjadikan kota yang berkedudukan di Afrika Utara ini lebih otonom dan mandiri dalam mengelola kekayaannya. Pada 1771

30 Uğur Kömeçoğlu, "Homo Ludens ve Homo Sapiens Arasında Kamusallık ve Toplumsallık: Osmanlı Kahvehaneleri," dalam Ahmet Yaşar (ed), Osmanlı Kahvehaneleri: Mekan, Sosyalleşme, iktidar (Istanbul: Kitap Yayinevi, 2010), hlm 57.

${ }^{31}$ Robert Mantran, XVI-XVIII Yüzyılda Osmanlı Imparatorluğu, hIm 64. 
kedai kopi di buka di komplek-komplek pertokoan atau khan yang dibangun di sepanjang sungai Nil yang disebut Bulaq. ${ }^{32}$ Sejarawan Alan Mikhail (2007) juga menyatakan bahwa kedai kopi tumbuh bersamaan dengan semakin ramainya penduduk yang menempati suatu wilayah. Hal tersebut ditunjukan dengan istana besar yang dibangun oleh pembesar Mesir bernama Amir Qasim Bey Abu Sayf. Dia membangun istana yang dipenuhi oleh kebun yang dihiasi oleh kolam serta pohon. Istana ini dibuka untuk publik. Ketika semakin banyak publik yang datang ke istana tersebut, maka Amir Qasim Bey Abu Sayf kemudian langsung membuka kedai kopi. ${ }^{33}$ Dengan demikian kopi menjadi simbol kesenangan dan waktu luang bagi masyarakat Usmani pada abad ke-18. Selain itu, kedai kopi menjadi wadah sosialisasi dan berkumpul masyarakat. Seorang Inggris bernama John Fryer menulis bahwa pada abad ke-17, pada malam hari orang-orang datang ke kafe Persia untuk meminum kopi. Sejarawan Mesir, al-Jabarti, juga menulis bagaimana pada bulan Ramadhan orang-orang menghabiskan waktunya baik di rumah maupun di kedai kopi. ${ }^{34}$ Dengan demikian kopi telah mejadi fenomena urban yang populer di masyarakat, khususnya di kota-kota besar, seperti Istanbul, Kairo hingga Aleppo. Dengan semakin populernya budaya minum kopi di tengah masyarakat Usmani, maka permintaan akan produk kopi juga semakin meningkat. Ini berarti kopi telah mendatangkan potensi bisnis yang sangat menguntungkan.

${ }^{32}$ Alan Mikhail, "The Heart's Desire: Gender, Urban, Space, and Ottoman Coffee House," dalam Dana Sajdi (ed), Ottoman Tulips, Ottoman Coffee: Leisure and Lifestyle in the Eighteenth Century (New York \& London: IB Tauris, 2007), hlm 139.

${ }^{33}$ Alan Mikhail, "The Heart's Desire," hlm 160.

${ }^{34}$ Alan Mikhail, "The Heart's Desire," hIm 142. 
Pada akhir abad ke-17, kopi mulai disebarkan ke Eropa. Mereka mulai berusaha mencari kopi untuk dijual kembali di Eropa. Para pedagang Eropa membeli produk kopi di Istanbul dan Kairo. Kebanyakan para pedagang yang membeli kopi adalah pedagang Venezia. Namun, kopi tidak terlalu banyak diminati saat itu. Baru pada abad ke-18, para pedagang Prancis dan Inggris mulai membawa produk kopi dari Kepulauan Karayip. Dengan demikian Inggris dan Prancis mulai membuat tandingan terhadap produk kopi Yaman. ${ }^{35}$ Selain itu, Belanda, melalui Perusahaan Dagang Hindia Timur (VOC), juga mulai masuk dalam kompetisi perdagangan kopi. Belanda mulai terlibat dalam perdagangan kopi pada abad ke-17 di Laut Merah dan Teluk Persia. Kopi-kopi tersebut diimpor ke Jawa pada akhir abad ke17 melalui mediasi para pedagang Muslim. Kopi pun diuji coba untuk ditanam di kebun-kebun milik petinggi VOC. Mengetahui bahwa kopi dapat di Jawa, maka para direktur VOC di Amsterdam mengirimkan surat kepada Gubernur Jenderal Van Hoorn di Batavia (Jakarta) untuk melakukan penanaman kopi di Jawa. Kopi mulai ditanam di Batavia dan Cirebon. Namun, bupati pertama yang menerima perintah untuk melakukan penanaman kopi adalah Bupati Cianjur. Penanaman kopi di wilayah Priangan, khususnya Cianjur, berbuah sukses. Pada 1726, VOC mampu mengontrol 3/4 perdagangan kopi secara global. ${ }^{36}$ Dengan demikian, kolonialisme Belanda juga turut membantu 'bom kopi' dalam pasar global.

${ }^{35}$ Suraiya Faroqhi, Osmanlı Kültürü ve Gündelik Yaşam, hlm 59.

${ }^{36}$ Jan Breman, Mobilizing Labour for Global Coffee Market: Profits from the Unfree Work Regime in Colonial Java (Amsterdam: Amsterdam University Press, 2015), hlm 65. 
Keberhasilan penanaman kopi di Priangan telah membantu persebaran kopi di seluruh dunia, khususnya Eropa.

\section{Janisari dan Bisnis Kedai Kopi}

Jika abad ke-16 dan 17, kopi mengalami sejarah pahit karena selalu diharamkan oleh otoritas Negara Usmani, maka pada abad ke18 bisnis kedai kopi semakin marak karena permintaan kopi oleh pasar global terus meningkat. Hal ini direspon secara pragmatis oleh keterlibatan tentara Janisari dalam bisnis ini. Seperti yang telah diketahui, tentara Janisari adalah pasukan infanteri elite Negara Usmani yang sudah ada sejak zaman pemerintahan Orhan Ghazi. ${ }^{37}$ Tidak ada yang mengetahui secara pasti kapan tentara Janisari dibentuk, namun beberapa catatan merujuk pembentukan Janisari pada hubungan Orhan Ghazi (1323-1362) dan Hacı Bektaş Veli. Sebelum membentuk tentara khusus, Orhan Ghazi terlebih dahulu meminta izin kepada Hacı Bektaş Veli. ${ }^{38}$ Versi lain menyatakan bahwa tentara Janisari dibentuk pada masa pemerintahan Sultan Murat I Hudevandigar (1362-1389). Hal ini dikaitkan pada keberhasilan Murat I dalam menaklukan wilayah-wilayah Balkan. Para anak-anak dari wilayah Balkan kemudian diambil dan dididik oleh Negara Usmani untuk menjadi pasukan Janisari.

Dalam merekrut tentara Janisari, Usmani menerapkan sistem devsirme. Sistem ini diadopsi dari Negara Mamluk yang mengambil para tentaranya dari para budak tawanan perang atau budak yang

${ }^{37}$ Orhan Ghazi adalah anak dari pendiri dinasti Usmani, Osman Ghazi. Salah satu prestasi Orhan Ghazi dalam memerintah Negara Usmani adalah keberhasilannya dalam menaklukan kota Bursa. Setelah berhasil ditaklukan, Usmani menjadi Bursa sebagai ibu kotanya, sebelum kemudian dipindahkan ke Edirne dan Istanbul pada 1453.

${ }^{38}$ Abdülkadir Sezgin. Hacı Bektaş Veli ve Bektaşilik (Ankara: Akçağ, 2012), hlm 64. 291

Tamaddun: Jurnal Sejarah dan Kebudayaan Islam, Volume (8), Issue (2),Desember 2020 
diperjualbelikan. Mereka kemudian dilatih dan dididik untuk menjadi tentara tangguh. Praktik ini kemudian diadopsi oleh Negara Usmani untuk membentuk tentara infenteri profesional. Setelah Usmani meluaskan wilayah kekuasaanya hingga ke Eropa Tenggara atau Balkan, maka Usmani mendapatkan sumber daya manusia yang dapat dimanfaatkan untuk mendukung ekspansi militernya. Otoritas Usmani kemudian merekrut anak-anak yang berasal dari keluarga Kristen di Balkan untuk dijadikan tentara. Mereka dibawa ke Istanbul dan Anatolia untuk dilatih menjadi seorang askeri (elite Usmani). Diantaranya nanti akan menempati posisi strategis, seperti perdana menteri atau sadrazam. Sudah banyak contoh anak-anak Balkan yang menjadi sadrazam Usmani. Rustem Pasa merupakan salah satu contoh produk devsirme yang berhasil menduduki jabatan sebagai sadrazam.

Mereka yang telah terlatih melalui sistem devsirme kemudian diangkat sebagai tentara Janisari. Tentara elite ini sangatlah terlatih sehingga menjadi pasukan penting, di samping Sipahi, yang membantu sultan dalam setiap ekspedisi. Abad ke-16 dan 17 menjadi periode penting bagi masa keemasan Janisari. Namun, pada abad ke18, pamor tentara Janisari mulai menurun karena ketidakmampuan Janisari dalam menghadapi Eropa. Menurunnya kualitas Janisari dalam berperang disebabkan adanya nepotisme. Dengan adanya nepotisme maka kualitasi Janisari yang didapatkan oleh Usmani tidaklah baik. Jumlah Janisari semakin banyak, namun kualitasnya semakin menurun. Hal ini juga disebabikan oleh dihapuskannya sistem devsirme pada abad ke-18 sehingga jumlah dan kualitas 
tentara Janisari tidak terkontrol. Banyaknya jumlah Janisari juga berhubungan dengan krisis ekonomi yang melanda Usmani sehingga negara tidak mampu mencukupi kebutuhan ekonomi Janisari. Untuk itu para Janisari mencoba mencari peluang lain dalam memenuhi kebutuhan hidupnya, salah satunya dengan membuka bisnis kedai kopi.

Dengan membuka bisnis kedai kopi, maka tentara Janisari secara langsung terkoneksi dengan kehidupan masyarakat sipil. Mereka tidak fokus dengan tugas kemiliteran, namun malah berusaha bergabung dengan kegiatan bisnis. Hal ini kemudian disebut dengan "esnafisasi". ${ }^{39}$ Esnaf merupakan bahasa Turki untuk para pengusaha dan pebisnis. Ali Çaksu (2007) mencatat bagaimana mewah dan besarnya kedai kopi yang dimiliki oleh para Janisari di Istanbul. Kedai kopi tersebut biasanya dibangun di tempat-tempat strategis yang memiliki pemandangan indah, seperti di pinggir laut. Salah satu kedai kopi milik Janisari, misalnya, dibuka di Çardak İskelesi, Istanbul. Kedai ini dibangun dengan sangat indah dan cantik oleh arsitektur keluarga Balyan Armenia. ${ }^{40}$ Dengan dibagun oleh keluar Balyan, maka kita dapat mendapati bahwa pembangunannya pasti membutuhkan biaya yang mahal. Seperti kita ketahui bahwa keluarg Balyan memang sudah terkenal di Negara Usmani sebagai keluarga arsitek yang berkontribusi dalam pembangunan di Negara Usmani. Salah satu karya rancangan arsitektur dari keluarga Balyan yang

${ }^{39}$ Ali Çaksu, "Janissary Coffee House in Late Eighteenth Century Istanbul" Dana Sajdi (ed), Ottoman Tulips, Ottoman Coffee: Leisure and Lifestyle in the Eighteenth Century (New York \& London: IB Tauris, 2007), hlm 119.

${ }^{40}$ Ali Çaksu, "Janissary Coffee House in Late Eighteenth Century Istanbul”, hlm 120. 
paling monumental, tentu saja, adalah Istana Dolmabahçe yang terletak di pinggir Selat Bosporus, Istanbul.

Menurut sejarawan Ali Çaksu (2007), terdapat beberapa fungsi penting kedai kopi bagi tentara Janisari, diantaranya adalah sebagai pusat pemberontakan, pusat perkumpulan Bektasi pusat bisnis dan pusat klub mafia. ${ }^{41}$ Semuanya tidak akan dibahas satu persatu dalam makalah ini. Salah satu fungsi paling penting dari kedai kopi milik Janisari adalah sebagai pusat pemberontakan. Jika melihat sejarah, maka fungsi kedai kopi sebagai pusat pemberontakan tidaklah mengherankan karena memang sudah sejak dibukanya kedai kopi di Istanbul pada abad ke-16, bisnis ini selalu menjadi kontroversi. Kedai kopi seakan-akan menjadi tempat perkumpulan alternatif dan terpisah dari perekumpulan resmi yang diselenggarkan oleh pemerintah. Dengan demikian, gagasan alternatif, wacana dan isu alternatif juga mudah menyebar di kedai kopi. Kedai kopi menjadi tempat berkomunikasi dan melakukan sosialisasi ide-ide yang dianggap tabu pada masa itu. Untuk itu tidaklah mengherankan jika kedai kopi sering dianggap negatif oleh pemerintah dan diharamkan berkali-kali antara abad ke-16 dan 17.

Menjelang akhir abad ke-18, hubungan Janisari dan pemerintah Usmani tidak selalu harmonis. Sulitnya sultan mengontrol kekuatan Janisari seringkali menjadi penyebab konflik yang terjadi antara sultan dan Janisari sepanjang abad ke-18. Jumlah Janisari semakin banyak dan, bahkan, menjadi kekuatan yang menentukan untuk masa depan sultan. Peristiwa pembunuhan

\footnotetext{
${ }^{41}$ Ali Çaksu, “Janissary Coffee House in Late Eighteenth Century Istanbul”, hlm 122-131. 294
}

Tamaddun: Jurnal Sejarah dan Kebudayaan Islam, Volume (8), Issue (2),Desember 2020 
Osman II menunjukan betapa kuatnya pengaruh Janisari dalam menentukan masa depan karir seorang sultan. Sebagaimana diketehui bahwa Osman II merupakan sultan yang ingin melakukan reformasi terhadap militer Usmani. Namun, hal ini tidak disetujui oleh Janisari karena dikhawatirkan akan ada tentara baru yang menggantikan Janisari. Mengetahui hal tersebut, Osman II dibunuh dalam sebuah huru hara di kota Istanbul. Para Janisari yang melakukan oposisi terhadap Osman II tentu saja banyak menyembunyikan aktivitasnya di kedai-kedai kopi. ${ }^{42}$ Sementara banyak lagi contoh bagaimana kedai kopi menjadi pusat pertemuan para Janisari yang tidak setuju dengan kebijakan-kebijakan sultan. Pada tahun 1730 terdapat pemberontakan terhadap sultan yang dinamakan Pemberontakan Patrona Halil. Para pemberontak melakukan pertemuan di kedai-kedai kopi untuk mendapatkan dukungan dari Janisari, pengrajin hingga pedagang. Pada tahun 1808, bodiguard dari Sadrazam Alemdar Mustafa Pasa telah memukuli beberapa tentara Janisari. Para Janisari tersebut kemudian datang dan berkumpul di kedai kopi untuk melakukan komplain terhadap perlakuan yang diterimanya. Setelah itu Alemdar Mustafa Paşa menerima ancaman mati. Tak lama kemudian Alemdar Mustafa Paşa pun terbunuh. ${ }^{43}$

Kritik terhadap pemerintah seringkali juga dilakukan di kedaikedai kopi. Seperti yang telah disebutkan sebelumnya bahwa kedai kopi merupakan tempat melakukan diskusi (söhbet) terhadap suatu permasalahan. Salah satu media yang digunakan untuk melakukan kritik terhadap pemerintah adalah melalui pertunjukan teater.

\footnotetext{
${ }^{42}$ Salah Birsel, Kahveler Kitabı, hlm 14.

${ }^{43}$ Ali Çaksu, "Janissary Coffee House in Late Eighteenth Century Istanbul”, hlm 124. 
Pertunjukan yang dimaksud adalah pertunjukan 'Wayang Turki' atau Karağöz. Karağöz merupakan tokoh pewayangan khas Turki yang dimainkan seperti wayang kulit di Jawa. Sebelum adanya surat kabar, pertunjukan Karağöz merupakan media untuk menyampaikan pesan dan informasi yang efektif. ${ }^{44}$ Dengan demikian pertunjukan Karağöz dapat diterima di kedai-kedai kopi. Selain mendapatkan hiburan, masyarakat juga dapat mengetahui informasi dan berita-berita yang dituangkan dalam pertunjukan wayang Karağöz.

Selain sebagai pusat pemberontakan, banyak kedai kopi yang dimiliki oleh Janisari juga menjadi tempat berkumpul para pengikut tarekat Bektasi. Seperti yang sudah diketahui sebelumnya bahwa pembentukan tentara Janisari tidak dapat dilepaskan dari peran Hac1 Bektaş Veli. Bahkan, para syaikh Bektasi kemudian memainkan peran penting di dalam korps Janisari itu sendiri. Para Janisari kebanyakan adalah pengikut para syaikh Bektasi. Kuatnya pengaruh tarekat Bektasi di dalam korps tentara Janisari tentu tidak dapat dipungkiri. Para syaikh Bektasi selalu menjadi pemimpin spiritual bagi Janisari. Ketika para Janisari memiliki kedai-kedai kopi yang tersebar di kotakota Usmani, maka kedai kopi menjadi tempat berkumpulnya para pengikut tarekat Bektasi. Kedai kopi bahkan sudah menyerupai pondok (tekke) dari tarekat Bektasi itu sendiri. Kuatnya pengaruh tarekat Bektasi terhadap kedai kopi miliki para Janisari terlihat ketika terdapat upacara pembukaan kedai kopi itu. Pembukaan kedai kopi

\footnotetext{
${ }^{44}$ Ahmet Yaşar, "Erken Modern Osmanlı'da Kahvehane Yasakmaları," hlm 44. 
milik Janisari dilakukan dengan upacara seremonial yang diiringi oleh pemuka tarekat Bektasi. ${ }^{45}$

Tarekat Bektasi tentu saja berbeda dari perkumpulan ulama yang didukung oleh pemerintah. Jika ulama-ulama pemerintah yang diwakili oleh seyhulislam, mufti dan kadi banyak yang mengharamkan kopi dan kedai kopi, maka hal tersebut tidak berlaku bagi para penganut Bektasi. Meskipun kopi telah dilarang oleh para ulama, namun pondok-pondok tarekat Bektasi tetap menyediakan kopi untuk dikonsumsi. ${ }^{46}$ Sikap tarekat Bektasi terhadap kopi juga tentu saja mempengaruhi cara pandang Janisari terhadap bisnis kedai kopi. Karena para syaikh Bektasi tidak mengharamkan kopi, bahkan menyediakan kopi di pondok-pondoknya, maka Janisari tidak mempermasalahkan status kopi itu sendiri. Mereka bahkan mencari keuntungan dari kopi dengan membuka kedai-kedai di tempattempat yang strategis. Keberanian Bektasi dalam menyediakan kopi tentu saja tidak lepas dari koneksi dan pengaruh yang kuat di dalam tentara Janisari. Keberadaan bisnis kedai kopi Janisari dan tarekat Bektasi terus menguat hingga tahun 1826. Pada tahun tersebut Sultan Mahmud II menghancurkan tentara Janisari karena ingin melakukan reformasi terhadap birokrasi dan militer. Untuk mencapai tujuannya maka Mahmud II harus terlebih dahulu menghancurkan Janisari sebagai kekuatan yang selalu menghalangi upaya pembaharuan dan reformasi. Setelah Janisari dihancurkan pada 1826, maka kedai-kedai kopi miliki Janisari pun ditutup. Bahkan tarekat Bektasi pun kemudian dilarang oleh Negara Usmani.

\footnotetext{
${ }^{45}$ Ali Çaksu, "Janissary Coffee House in Late Eighteenth Century Istanbul", hlm 127.

${ }^{46}$ Suraiya Faroqhi, Anadolu'da Bektaşilik (i̇stanbul: Simurg, 2003), hlm 139-140. 


\section{Penutup}

Kedatangan kopi di Negara Usmani pada pertengahan abad ke-16 telah memunculkan wacana baru dalam melihat sebuah produk. Kopi tidak hanya mengubah selera konsumsi masyarakat Usmani, tetapi juga telah mengubah bagaimana cara masyarakat Usmani mendapatkan kesenangan dan membuka ruang publik yang digunakan untuk melakukan komunikasi secara efektif. Meskipun pada awalnya kedatangan kopi diharamkan oleh pemerintah dan otoritas keagamaan, namun lambat laun kopi menjadi produk yang disukai oleh kalangan masyarakat Usmani. Pada abad ke-16 dan 17, kita dapat melihat bagaimana para sultan Usmani menginstruksikan para ulama untuk mengharamkan kopi. Namun, pada saat yang bersamaan banyak kedai kopi yang bermunculan di kota-kota besar Usmani, seperti Istanbul dan Kairo.

Kemunculan kedai kopi di kota-kota tersebut terjadi bersamaan dengan meningkatnya kesejahteraan ekonomi dan kebutuhan masyarakat urban. Dengan perkembangan kota-kota yang sangat pesat, maka masyarakat Usmani membutuhkan ruang untuk berinteraksi dan berkomunikasi. Kedatangan produk kopi telah memunculkan kesenangan dan hiburan yang menyatukan masyarakat Usmani sehingga kedai-kedai kopi ramai dikunjungi. Di sanalah masyarakat Usmani berinteraksi dalam sebuah ruang publik yang terbuka. Berita, informasi, hingga desas-desus politik menjadi ramai dibicarakan di kedai-kedai kopi. Di sanalah berkumpul berbagai elemen masyarakat dari mulai birokrat, tentara, pedagang hingga pengrajin. Keberadaan kedai kopi semakin ramai pada abad 
ke-18. Ketika itu tentara Janisari ikut serta bergabung dalam komunitas sipil dengan cara membuka bisnis kedai kopi. Ketika hubungan antara Janisari dan sultan tidak harmonis, maka kedaikedai kopi tersebut banyak dicurigai sebagai tempat para pemberontak berkumpul.

Dengan demikian, kita dapat mengetahui bahwa membicarakan kopi di Negara Usmani pada periode modern awal bukan saja membicarakan tentang minuman biasa. Kopi telah menjelma menjadi produk yang bermanfaat untuk membangun pola interaksi sosial ekonomi masyarakat Usmani. Budaya minum kopi telah mengubah perspektif orang Usmani mengenai cara berkumpul dan berkomunikasi. Ketika kedai kopi berkembang dengan sangat pesat di kota-kota Usmani, maka berkembang juga ruang publik yang menyediakan tempat untuk bersosialisasi dan berbagi informasi. Untuk itu kemunculan kopi juga telah membuka budaya konsumsi yang mendorong masyarakat untuk berkumpul bersama di ruang publik.

\section{Referensi}

Açıkgöz, Namık, Kahvename: Klasik Türk Edebiyatında Kahve (Ankara: Akçağ, 1999).

Aydemir, Abdullah, Ebusuud Efendi (Ankara: Kültür Bakanlığ1 Yayınlar1, 1989).

Birsel, Salah, Kahveler Kitabı (Ankara: Türkiye İş Bankası Kültür Yayınlar1, 1983).

Breman, Jan, Mobilizing Labour for Global Coffee Market: Profits from the Unfree Work Regime in Colonial Java (Amsterdam: Amsterdam University Press, 2015)

Çaksu, Ali, "Janissary Coffee House in Late Eighteenth Century Istanbul” Dana Sajdi (ed), Ottoman Tulips, Ottoman Coffee: Leisure 
and Lifestyle in the Eighteenth Century (New York \& London: IB Tauris, 2007).

Evliya Çelebi, Günümüz Türkçesiyle Evliya Çelebi Seyahatnamesi: İstanbul (1.Kitap 1.Cilt) (editor: Seyit Ali Karaman Yüceli Dağl1) (İstanbul: Yap1 Kredi Yayınları, 2006).

Faroqhi, Suraiya, Anadolu'da Bektaşilik (İstanbul: Simurg, 2003).

Kafadar, Cemal, "How Dark is the History of Night, How the Black The Story of Coffee, How Bitter the Tale of Love: The Changing Measure of Leisure and Pleisure in Early Modern Istanbul," dalam Arzu Ozturkmen \& Evelyn Birge Vitz, Medieval and Early Modern Performances in the Eastern Mediterranean (Turnhout: Brepols, 2014).

Katip Çelebi, Mizanu'l- hak fi ihtiyari'l - ehak: İslam'da Tenkid ve Tartışma Usulu (editor: Suleyman Uludag \& Mustafa Kara) (İstanbul: Marifet Yayınları, 1990).

Kömeçoğlu, Uğur, "Homo Ludens ve Homo Sapiens Arasında Kamusallık ve Toplumsallık: Osmanlı Kahvehaneleri," dalam Ahmet Yaşar (ed), Osmanlı Kahvehaneleri: Mekan, Sosyalleşme, Iktidar (Istanbul: Kitap Yayinevi, 2010).

Mantran, Robert, XVI-XVIII Yüzyılda Osmanlı Imparatorluğu (penerjemah: Mehmet Ali Kılıçbay) (Ankara: İmge Kitabevi, 1995).

Mikhail, Alan, "The Heart's Desire: Gender, Urban, Space, and Ottoman Coffee House," dalam Dana Sajdi (ed), Ottoman Tulips, Ottoman Coffee: Leisure and Lifestyle in the Eighteenth Century (New York \& London: IB Tauris, 2007).

Peçevi İbrahim Efendi, Peçevi Tarihi I (editor: Bekir Sıtkı Baykal) (Ankara: Kültür Bakanlığı Yayınları, 1981).

Sezgin, Abdülkadir,. Hacı Bektaş Veli ve Bektaşilik (Ankara: Akçağ, 2012).

Tansel, Selahattin Yavuz Sultan Selim (Ankara: Milli Eğitim Basımevi: 1969)

Tosun, Necdet, "Veysel Karani," dalam Diyanet Islam Ansiklopedisi jilid 43 (2013), hlm 74-75

Yaşar, Ahmet "Giriş: Geçmişini Arayan Osmanlı Kahvehanesi", dalam Ahmet Yaşar (ed), Osmanl Kahvehaneleri: Mekan, Sosyalleşme, İktidar (Istanbul: Kitap Yayinevi, 2010). 
Yaşar, Ahmet, "Erken Modern Osmanlı'da Kahvehane Yasakmaları," dalam Ahmet Yaşar (ed), Osmanl Kahvehaneleri: Mekan, Sosyalleşme, İktidar (Istanbul: Kitap Yayinevi, 2010).

Tamaddun: Jurnal Sejarah dan Kebudayaan Islam, Volume (8), Issue (2),Desember 2020 